\title{
PERSONAL SENSITIVITY, SELF-MEDICATION, MASK USAGE, AND COVID-19 SYMPTOMS IN SUB-SAHARAN AFRICANS
}

\author{
SAHRA ALTI AFRIKALILAR ARASINDA KIŞISEL DUYARLILIK, KENDI KENDINE ILAÇ \\ TEDAVISI, MASKE KULLANIMI VE COVID-19 BELIRTILERI
}

\author{
Tosin Yinka AKINTUNDE ${ }^{1}$, Shaojun CHEN $^{1}$ (D), Oluwatosin Imoleayo OYENIRAN² (D), Monday Alexander ETUH ${ }^{3}$, \\ Angwi Enow TASSANG ${ }^{1}$ (D), Terkuma $\mathrm{CHIA}^{4}$ (D), Felix Oluseyi $\mathrm{AMOO}^{5}$ (i)

\begin{abstract}
${ }^{1}$ Hohai University, School of Public Administration, Department of Sociology, Nanjing, PR, China
${ }^{2}$ Nile University of Nigeria, College of Health Sciences, Faculty of Basic Medical Sciences, Department of Physiology, Abuja, Nigeria ${ }^{3}$ University of Jos, Faculty of Natural Science, Department of Zoology, Applied Entomology and Parasitology Unit, Nigeria ${ }^{4}$ Niles University of Nigeria, College of Health Sciences, Faculty of Basic Medical Sciences, Department of Anatomy, Abuja, Nigeria ${ }^{5}$ University of Ibadan, Institute for Peace and Conflict Studies, Ibadan, Oyo State, Nigeria
\end{abstract}

ORCID IDs of the authors: T.Y.A. 0000-0002-9392-8726; S.C. 0000-0003-2938-2391; O.I.O. 0000-0001-6720-8453; M.A.E. 0000-0002-2875-8169; A.E.T. 0000-0003-2690-5150; T.C. 0000-0002-3257-459X; F.O.A. 0000-0002-2408-9746

Cite this article as: Akintunde TY, Chen S, Oyeniran OI, Etuh MA, Tassang AE, Chia T, et al. Personal sensitivity, self-medication, mask usage, and COVID-19 symptoms in Sub-Saharan Africans. J Ist Faculty Med. Published online February 24, 2022. doi: 10.26650/IUITFD.945803

\section{ABSTRACT}

Objective: The study objective was to explore the episode of COVID-19 symptoms among sub-Saharan African (SSA) by examining the predicting effect of mask usage, self-medication, and personal sensitivity on the symptoms.

Materials and Methods: In a cross-sectional study in the SSA population, 536 individuals were asked about the episode of COVID-19 symptoms, personal sensitivity, mask usage, and self-medication. "Hierarchical multiple linear regression statistical method" was used to evaluate the data.

Results: The personal sensitivity $(r=0.245<0.01)$, taking off face mask in enclosed public places $(r=0.255<0.01)$ and self-medication $(r=0.392<0.01)$ were positively associated with COVID-19 symptoms. Overall, the total predictive effect of self-medication, taking off the mask in public spaces, and personal sensitivity accounted for $21 \%$ of the variance in the episode of COVID-19 symptoms of the study population.

Conclusion: Personal sensitivity, mask usage, and self-medication support understanding of the episode of COVID-19 symptoms experienced among the study population. It is important to encourage the use of masks in high-risk areas. To improve post-COVID-19 health policies, self-medication used to decrease the risk of COVID-19 infection and other related public health concerns should be reduced.

Keywords: Self-medication, mask usage, personal sensitivity, COVID-19, Sub-Saharan Africans

\section{ÖZET}

Amaç: Çalışmanın amacı, Sahra Altı Afrikalı (SAA) bireylerde kişisel koruyucu ekipman kullanımının ve kendi kendine ilaç tedavisinin, COVID-19 semptomlarının ortaya çıkması üzerine olan etkisini araştırmaktır.

Gereç ve Yöntem: SAA popülasyonunda 536 kişi üzerinde yapılan kesitsel bir ankette COVID-19 semptomları, kişisel duyarlılık, maske kullanımı ve halk arasında benimsenen kendi kendine tedavi yöntemleri değerlendirilerek kaydedildi. İstatistiksel metod olarak "Hiyerarşik çoklu doğrusal regresyon modelleme" kullanıldı.

Bulgular: Kişisel duyarlılık $(r=0,245<0,01)$, halka açık kapalı alanlarda yüz maskesinin çıkarılması $(r=0,255<0,01)$ ve kendi kendine ilaç tedavisi $(r=0,392<0,01)$ COVID-19 semptomları ile pozitif olarak ilişkiliydi. Genel olarak, kendi kendine ilaç tedavisinin, kamusal alanlarda maskeyi çıkarmanın ve kişisel duyarlıığın toplam öngörücü etkisi, çalışma popülasyonunun COVID-19 semptomları epizodundaki varyansın \%21'ini oluşturdu.

Sonuç: Kişisel duyarlılık, maske kullanımı ve kendi kendine ilaç tedavisi, çalışma popülasyonunda yaşanan COVID-19 semptomlarının epizodunun anlaşımasını destekler. Yüksek riskli bölgelerde maske kullanımının teşvik edilmesi önemlidir. COVID-19 sonrası sağlık politikalarının iyileştirilmesi için COVID-19 enfeksiyonu riskini ve diğer ilgili halk sağlığı endişelerini azaltmak için kullanılan kendi kendine ilaç tedavisi azaltılmalıdır.

Anahtar Kelimeler: Kendi kendine tedavi, maske kullanımı, bağışıklık, COVID-19, Sahra Altı Afrikalılar

Corresponding author/iletişim kurulacak yazar: akintunde.ty@hhu.edu.cn, akintunde_olayinka@yahoo.com

Submitted/Başvuru: 09.06.2021 • Revision Requested/Revizyon Talebi: 26.08.2021 •

Last Revision Received/Son Revizyon: 18.01.2022 • Accepted/Kabul: 19.01.2022 • Published Online/Online Yayın: 24.02.2022 


\section{INTRODUCTION}

The Severe Acute Respiratory Syndrome Coronavirus 2 (SARS-CoV-2), the virus responsible for the COVID-19 pandemic, has caused global disruption due to the diseases' spread rate and mortality (1). While global vaccine implementation is underway, there is still concern about Africa's vulnerability to COVID-19 infections due to the weak healthcare systems, insufficient checking and tracing systems, overstretched healthcare facilities, and limited resources (2-5).

Self-medication causes public health concern focusing on the safety of self-administration of drugs, causes antibiotic resistance, and may lead to death (6-9). Meanwhile, mask usage has become a symbol of social responsibility, and it is an essential tool for personal protection against COVID-19 (10-14). Sensitivity is a concept of awareness of risk (15). Considerable evidence has supported the mediating role of sensitivity to the risk of contracting infectious diseases (16-18). While the concept of personal sensitivity to disease remains relevant and has a psychomedical implication, more evidence is needed to establish the influence of COVID-19 infection among vulnerable populations. These indicators may help to understand COVID-19 symptom experience among the study group. Following the World Health Organization (WHO), the apparent incidences of COVID-19 symptoms are dry cough, fever, and tiredness, among others (19). Hence, mask usage (as one of the crucial protection measures), self-medication (that may distort medical action, early detection of COVID-19 and intervention), and personal sensitivity to understand health decisions and risk.

The current study examined the association of personal sensitivity, mask usage, and self-medication on COVID-19 symptoms among a group of SSAs. The study also examined the predictive effects of self-medication, mask usage, and personal sensitivity on the episode of COVID-19 symptoms. The evidence presented supports understanding the three vital domains' influence on unreported COVID-19 symptoms experienced in the study population.

\section{MATERIALS AND METHODS}

\section{Study design, population, and data collection}

Data from a sample of 536 sub-Saharan Africans were analyzed. A cross-sectional study design was adopted to extract information on the usage of masks and the personal sensitivity to COVID-19 from sub-Saharan Africans in Nigeria, Cameroun, China, South Africa, and others living in Diaspora between 18-24 August 2020. All participants were between 19 years or older $(60 \geq)$ with access to internet facilities and social media platforms. Data collection was carried out over seven days. A simple snowballing method was used through referral via Facebook, WhatsApp, Instagram, and We Chat (for SSA migrant residents in China).

\section{Episodes of COVID-19 symptoms}

The episodes of COVID-19 symptoms were measured using the WHO indicators (22). We solicited information on COVID-19 symptoms experienced by respondents in the last 60 days before the survey. Twelve counts of COVID-19 symptoms were asked in dichotomous (yes/ no) questions. Upon collection of data, a reliability test was estimated to establish the reliability of the collected data. The episodes of COVID-19 symptoms reliability test had a Cronbach's coefficient alpha ${ }^{2} \alpha$ of 0.824 with an analysis of variance significant at 0.001 .

\section{Personal sensitivity}

The personal sensitivity questionnaire was adopted from existing studies on vulnerability $(20,21)$. The six items to evaluate participants' sensitivity and the questions were adjusted to fit one's chances of infection and exposure to COVID-19. The six items were ranked with a 5-point Likert type scale ranging from strongly disagree to strongly agree, with a question like "There is a great chance that I will be exposed to chronic disease (19)." The reliability test result of Cronbach's coefficient alpha ${ }^{2}=0.838$ with an analysis of variance significant at 0.001 .

\section{Control variables}

Data on respondents' age, marital status, education attainment were collected. The respondents' ages were grouped into six categories as $\leq 19,20-29,30-39,40-49$, $50-59,60 \geq$ in the questionnaire. The employment status was a dichotomous question ( $\mathrm{No}=1$, Yes=2), while marital status was categorized into five categories, i.e., Single, in partnership but not married, married, divorced or separated, widowed. Information on health-seeking options in the 60 days preceding the survey was asked in three dichotomous questions such as: "visit a hospital," "used prescription drugs,"

"self-medicated." The use of masks was measured with four basic questions of SSA's daily habit on mask usage in the following form: use of face mask every time, the importance of face mask in the pandemic, mask use in enclosed areas, and perception of the effectiveness of face masks.

\section{Data analysis}

Data collected from the questionnaire was extracted into Microsoft Excel and imported into SPSS version 25 for analysis. Descriptive analysis, including mean and standard deviation, was used to measure respondents' demographics and socioeconomic characteristics. To establish the association between variables, we employed correlation matrix analysis to establish an association between demographic/ socioeconomic characteristics and mask usage. Similarly, a correlation matrix was used to measure the association between demographic/socioeconomic characteristics of the study population and other research variables. The interpretation of correlation coefficients were small $(r=0.10)$, medium ( $r=0.30$ ) or large ( $r=0.50)(22)$. Hierarchical multiple 
regression analysis was used to evaluate the predictive effect of self-medication on COVID-19 symptoms as Model 1. Two additional variables completed the regression analysis, such as the added effects of taking off masks (Model 2) and personal sensitivity (Model 3).

\section{RESULTS}

\section{Demographic/socioeconomic characteristics of SSAs} study population

The descriptive statistic as shown in Table 1 shows the frequency result for gender as female (55\%) and male (45\%) with a mean $=1.45(\mathrm{SD}=0.49)$. The distribution of mean and standard deviation of respondents are as follows; ages (2.42 \pm 0.85$)$, marital status $(1.7 \pm 0.96)$, educational attainment (4.4 \pm 0.62$)$, and employment status $(1.55 \pm 0.50)$. The details of respondents' demographic and socioeconomic characteristics are presented in Table 1.

The data from Table 2 shows that at least two out of ten (21.5\%) of every SSA enumerated visited the hospital in the last 60 days before the survey. Meanwhile, 27.8\% had used prescription drugs 60 days before the study, while almost four out of ten had self-medicated. Based on mask usage,

Table 1: Demographic/socio economics characteristics of Sub-Saharan Africans $(n=536)$

\begin{tabular}{lccc}
\hline Variables & $\%$ & Mean & SD \\
\hline Gender & & 1.45 & 0.49 \\
\hline Female & 55.0 & & \\
$\quad$ Male & 45.0 & & \\
Age & & 2.42 & 0.85 \\
\hline$\leq 19$ & 5.6 & & \\
$20-29$ & 49.1 & & \\
$30-39$ & 37.1 & & \\
$40-49$ & 5.4 & & \\
$50-59$ & 1.5 & & \\
60 $\geq$ & 1.3 & & \\
Marital status & & 1.77 & 0.96 \\
\hline Single & 56.5 & & \\
In partnership & 12.5 & & \\
$\quad$ Married & 29.1 & & \\
Separated/divorced & 1.1 & & \\
$\quad$ Widowed & 0.7 & & \\
Education attainment & & 4.41 & 0.62 \\
\hline Secondary & 7.1 & & \\
$\quad$ Tertiary & 44.8 & & \\
Post graduate & 48.1 & & \\
Employment status & & 1.55 & 0.50 \\
\hline No & 44.6 & & \\
Yes & 55.4 & & \\
\hline
\end{tabular}

Medical-care seeking and mask usage among Sub-Saharan Africans $(n=536)$ at least one in four SSA study populations does not use a face mask every time. However, an insignificant proportion (4.1\%) believed that a face mask is not essential during a global pandemic. Overall, about $38.6 \%$ reported taking off face masks in public areas such as restaurants, supermarkets, car parks, and religious places, and about $17 \%$ concluded that face masks are ineffective.

A comparative association test was estimated for the

Table 2: Medical-care seeking and mask usage among SSAs surveyed $(n=536)$

\begin{tabular}{|c|c|c|c|}
\hline Variables & $\%$ & Mean & SD \\
\hline $\begin{array}{l}\text { Hospital visit in the } \\
\text { last } 60 \text { days }\end{array}$ & & 1.21 & 0.411 \\
\hline No & 78.5 & & \\
\hline Yes & 21.5 & & \\
\hline $\begin{array}{l}\text { Use prescription } \\
\text { medication in the } \\
\text { last } 60 \text { days }\end{array}$ & & 1.28 & 0.448 \\
\hline No & 72.2 & & \\
\hline Yes & 27.8 & & \\
\hline $\begin{array}{l}\text { Self-medicated in the } \\
\text { last } 60 \text { days }\end{array}$ & & 1.39 & 0.488 \\
\hline No & 61.2 & & \\
\hline Yes & 38.8 & & \\
\hline $\begin{array}{l}\text { Use of face mask } \\
\text { every time }\end{array}$ & & 1.74 & 0.442 \\
\hline No & 26.5 & & \\
\hline Yes & 73.5 & & \\
\hline $\begin{array}{l}\text { A face mask is important } \\
\text { during a pandemic }\end{array}$ & & 1.96 & 0.199 \\
\hline No & 4.1 & & \\
\hline Yes & 95.9 & & \\
\hline $\begin{array}{l}\text { Take off the mask in an } \\
\text { enclosed public area }\end{array}$ & & 1.39 & 0.487 \\
\hline No & 61.4 & & \\
\hline Yes & 38.6 & & \\
\hline $\begin{array}{l}\text { A face mask is } \\
\text { ineffective }\end{array}$ & & 1.18 & 0.384 \\
\hline No & 82.1 & & \\
\hline Yes & 17.9 & & \\
\hline
\end{tabular}

Descriptive analysis by the residency and taking off of masks in enclosed Public Areas of SSAs surveyed $(n=536)$

country of residency and taking off masks in enclosed public areas. Predominantly, a significant number of SSAs who reside in Nigeria (57.1\%) take off masks in enclosed public spaces. Similarly, about $15.5 \%$ of Cameroon respondents take off masks in enclosed public areas. Therefore, there was an association between the SSA under investigation and taking off of masks in enclosed public areas $\left(X^{2}=35.622, p<0.001\right)$. 
Table 3: Cross Tabulation by Country of residency and taking off of masks in enclosed Public Areas of Sub-Saharan Africans surveyed $(n=536)$

\begin{tabular}{lccc}
\hline $\begin{array}{l}\text { Country of } \\
\text { residency }\end{array}$ & Yes (n, \%) & No $(\mathbf{n}, \%)$ & $\mathbf{X}^{2}=\mathbf{3 5 . 6 2 2} 2^{\mathrm{a} / \mathrm{df}=\mathbf{6}}$ \\
\hline Nigeria & $118(57.1 \%)$ & $98(47.3 \%)$ & $\mathrm{p}<0.001$ \\
Cameroon & $51(15.5 \%)$ & $73(35.3 \%)$ & \\
China & $22(6.7 \%)$ & $13(6.3 \%)$ & \\
South-Africa & $11(3.3 \%)$ & $2(1 \%)$ & \\
Ghana & $10(3.0 \%)$ & $1(0.5 \%)$ & \\
Canada & $14(4.3 \%)$ & $2(1 \%)$ & \\
Others & $33(10.3 \%)$ & $18(8.7 \%)$ & \\
\hline
\end{tabular}

\section{Bivariate analysis: Correlation matrix}

The Pearson correlation coefficient matrix evaluated the association between COVID-19 symptoms, personal sensitivity, face mask usage, and demographic/socioeconomic characteristics of the SSA population surveyed. From Table 4, the personal sensitivity was positively cor- related with COVID-19 symptoms $(r=0.245<0.01)$. Using a face mask correlates inversely with COVID-19 symptoms $(r=-0.122<0.01)$. The importance of face masks is positively correlated with COVID-19 symptoms $(r=0.096<0.05)$. Taking off the face mask in enclosed public places was positively associated with COVID-19 symptoms $(r=0.255<0.01)$. The hospital visitation was associated with COVID-19 symptoms $(r=0.144<0.01)$. Similarly, prescription medication was correlated with COVID-19 symptoms $(r=0.272<0.01)$. Lastly, the use of self-medication was moderately correlated with COVID-19 symptoms $(r=0.392<0.01)$.

Education attainment was positively correlated with personal sensitivity $(r=0.086<0.05)$. Use of prescription medication shows positive correlation with personal sensitivity $(r=0.088<0.05)$. The use of self-medication was positively correlated to personal sensitivity $(r=0.196<0.01)$. Gender was negatively correlated with taking off the face mask in enclosed public places $(r=-0.108<0.05)$. Similarly, taking off the face mask in enclosed public places was negatively correlated with the marital status of SSA $(r=-0.090<0.05)$. The age of SSA was negatively correlated with taking off

Table 4: Pearson correlation matrix for COVID-19 symptoms, personal sensitivity, health-seeking, face mask usage, and demographic/socioeconomic characteristics of SSA surveyed $(n=536)$

\begin{tabular}{|c|c|c|c|c|c|c|c|c|c|c|c|c|c|c|}
\hline & 1 & 2 & 3 & 4 & 5 & 6 & 7 & 8 & 9 & 10 & 11 & 12 & 13 & 14 \\
\hline $\begin{array}{l}\text { COVID-19 } \\
\text { symptoms }\end{array}$ & 1 & & & & & & & & & & & & & \\
\hline $\begin{array}{l}\text { Personal } \\
\text { sensitivity }\end{array}$ & $0.245^{\star \star}$ & 1 & & & & & & & & & & & & \\
\hline Gender & -0.074 & -0.027 & 1 & & & & & & & & & & & \\
\hline Age & -0.022 & 0.074 & $0.220^{\star *}$ & 1 & & & & & & & & & & \\
\hline Marital status & 0.023 & 0.080 & 0.060 & $0.530^{\star *}$ & 1 & & & & & & & & & \\
\hline $\begin{array}{l}\text { Education } \\
\text { attainment }\end{array}$ & -0.031 & $0.086^{*}$ & $0.158^{* *}$ & $0.354^{* *}$ & $0.241^{* *}$ & 1 & & & & & & & & \\
\hline $\begin{array}{l}\text { Employment } \\
\text { status }\end{array}$ & -0.012 & 0.004 & $0.147^{\star \star}$ & $0.361^{\star *}$ & $0.358^{* *}$ & $0.176^{* *}$ & 1 & & & & & & & \\
\hline $\begin{array}{l}\text { Frequent } \\
\text { face-mask use }\end{array}$ & $-0.122^{\star *}$ & -0.008 & 0.007 & 0.020 & 0.055 & -0.019 & -0.020 & 1 & & & & & & \\
\hline $\begin{array}{l}\text { The face mask } \\
\text { is important }\end{array}$ & $0.096^{*}$ & -0.015 & -0.021 & 0.049 & -0.050 & -0.060 & -0.053 & $0.195^{\star \star}$ & 1 & & & & & \\
\hline $\begin{array}{l}\text { I take off my } \\
\text { face mask }\end{array}$ & $0.255^{\star \star}$ & 0.046 & $-0.108^{*}$ & $-0.185^{\star \star}$ & * $-0.090^{*}$ & -0.062 & $-0.090^{*}$ & ${ }^{*}-0.297^{* *}$ & $-0.126^{* *}$ & 1 & & & & \\
\hline $\begin{array}{l}\text { The face mask } \\
\text { is ineffective }\end{array}$ & 0.052 & -0.005 & -0.011 & -0.017 & -0.046 & 0.036 & -0.012 & $-0.105^{*}$ & $-0.320^{\text {** }}$ & * $0.199^{* *}$ & 1 & & & \\
\hline Hospital visit & $0.144^{\star \star}$ & 0.077 & 0.039 & 0.038 & 0.064 & 0.035 & 0.039 & 0.046 & 0.039 & -0.013 & 0.040 & 1 & & \\
\hline $\begin{array}{l}\text { Prescription } \\
\text { medication }\end{array}$ & $0.272^{\text {** }}$ & $0.088^{*}$ & -0.033 & 0.046 & 0.044 & -0.001 & 0.054 & 0.052 & $0.086^{*}$ & -0.022 & -0.051 & $0.508^{* *}$ & 1 & \\
\hline Self-medication & $0.392^{* *}$ & $0.196^{\star *}$ & -0.004 & 0.035 & -0.021 & 0.029 & 0.006 & $-0.121^{\star *}$ & -0.009 & $0.178^{\star *}$ & 0.037 & 0.013 & $0.155^{\star *}$ & 1 \\
\hline
\end{tabular}

Significant: ${ }^{*}: p<0.05,{ }^{* *}: p<0.01$ 
the mask in enclosed public areas $(r=-0.185<0.01)$. The employment status was inversely correlated with taking off the mask in an enclosed public area $(r=-0.090<0.05)$.

The "face mask is important" shows a moderate positive correlation with frequent usage of face mask $(r=0.195<0.01)$, while frequent use of face masks show a negative correlation with taking off face mask in enclosed public places $(r=-0.297<0.01)$. Meanwhile, "the face mask is ineffective" returned a negative correlation with the use of a face mask every time $(r=-0.105<0.05)$. The use of self-medication was negatively correlated with the consistent use of face masks $(r=-0.121<0.01$. Taking off the mask in enclosed public places was negatively correlated with face mask is important $(r=-0.126<0.01)$, and "face mask is ineffective" is negatively correlated with taking off the mask in public enclosed places $(r=-0.320<0.01)$. The use of prescription medication was positively correlated with face mask is important $(r=0.086<0.05)$. Face masks ineffective were positively associated with taking off masks in enclosed public places $(r=0.199<0.01)$; meanwhile, the use of self-medication was positively correlated with taking off face masks in enclosed public places $(r=0.178<0.01)$. Hospital visit was associated with the use of prescription medication $(r=0.508<0.01)$

\section{Regression model}

The multiple linear regressions were calculated to predict an episode of COVID-19 symptoms based on self-medication, taking off face masks in public, and personal sensitivity to COVID-19 infection. As presented in Table 5, the results show that the use of self-medication was sig- nificantly associated (Adjusted $R^{2}=0.15$ ) with an episode of COVID-19 symptoms. A different model (Model 2) exploring the predictive effect of taking off the mask in an enclosed public environment $(B=0.35, p<0.001)$ shows a significant association (Change in $R^{2}=0.035$ ) to the model predicting the episode of COVID-19 symptoms (Adjusted $R^{2}=0.19$ ). The third model (Model 3) of personal sensitivity to COVID-19 shows a significant additional effect to the model predicting the episode of COVID-19 symptoms among the study population (Adjusted $R^{2}=0.21$ ). Overall, the regression model highlighted that an estimation of $21 \%$ of the variance in the episode of COVID-19 symptoms is accounted for by self-medication, taking off face masks, and personal sensitivity.

\section{DISCUSSION}

The current study explored the effect of self-medication, mask usage, and personal sensitivity on the COVID-19 symptoms among surveyed SSAs. The evidence presented in this study supports the growing concern on the risk of self-medication, mask usage, and personal sensitivity as a determinant of risky health behaviors and adverse disease experiences globally. However, evidence has independently assessed risks, mask usages, and self-medication in COVID-19 infection exposure (23-25). However, this study evaluated the three domains to aggregate for their influence on COVID-19 symptoms among the study population.

The finding from the analysis shows that there is a direct association between personal sensitivity and COVID-19 symptoms. Increased personal sensitivity towards being infected with COVID-19 results in increased symptoms,

Table 5: Hierarchical multiple linear regression models assessing the association between COVID-19 Symptoms, Self-medication, Taking Off Face Masks in public, and Personal Sensitivity to COVID-19

\begin{tabular}{|c|c|c|c|c|c|c|c|c|c|}
\hline & \multicolumn{3}{|c|}{ Model 1} & \multicolumn{3}{|c|}{ Model 2} & \multicolumn{3}{|c|}{ Model 3} \\
\hline & B & $\beta$ & $\mathrm{p}$ & B & $\beta$ & $p$ & B & $\beta$ & $p$ \\
\hline Constant & 11.386 & & $<0.001$ & 10.206 & & $<0.001$ & 9.356 & & $<0.001$ \\
\hline Self-medication & 2.123 & 0.392 & $<0.001$ & 1.938 & 0.358 & $<0.001$ & 1.757 & 0.324 & $<0.001$ \\
\hline Mask off in public & & & & 1.036 & 0.191 & $<0.001$ & 1.025 & 0.189 & $<0.001$ \\
\hline Personal sensitivity & & & & & & & 0.100 & 0.173 & $<0.001$ \\
\hline \multicolumn{10}{|c|}{ Model fit Indices } \\
\hline
\end{tabular}

Adjusted $R^{2}=$

0.15

0.19

0.21

$\Delta F(d f 1, d f 2), p$-value:

$\Delta F(1,530)=96.118, p<0.001$

$\Delta F(1,529)=30.084, p<0.001$

$\Delta \mathrm{F}(1,528)=$

17.287, $p<0.001$

${ }^{*}$ Change in $\mathrm{R}^{2}$

0.154

0.035

0.029

* Change in $F, p$-value

96.118, $p<0.001$

23.005, $p<0.001$

19.420, $p<0.001$

Dependent variable: Episode of COVID-19 Symptoms

Model 1. Predictors: Constant, Self-Medication

Model 2. Predictors: Constant, Self-Medication, Taking Off Mask in Public

Model 3. Predictors: Constant, Self-Medication, Taking Off Mask in Public, Personal sensitivity 
supporting other studies that perceived risk aggravates fear, stress, and worry about getting infected with COVID-19 (26). The more adherence to face masks used, the lesser the episode of COVID-19 symptoms reported, which agrees with the evidence that mask use reduces the risk of COVID-19 disease (12). However, with the nonuse of masks in enclosed public places, there is a relative increase in COVID-19 symptoms experienced. The results also suggested self-medicating was associated with the COVID-19 symptoms experienced. Like other studies on risk to diseases, the increasing level of education of SSAs suggested a relative increase in the sensitivity to COVID-19 exposure $(27,28)$.

Self-medication practice among the study population increased COVID-19 symptoms. While taking off masks in enclosed public spaces was added to self-medication in Model 2, there is evidence of increased COVID-19 symptoms. Overall, the predictive effect of self-medication, taking off masks, and personal sensitivity explains a significant proportion of reported COVID-19 symptoms of SSAs under investigation. However, a substantial proportion of the COVID-19 symptoms reported by the study population was demonstrated by self-medication based on the result from the first model. Although there were added effects of improper mask usage and personal sensitivity on the personal sensitivity and COVID-19 symptoms, they added $3.5 \%$ and $2.9 \%$, respectively, to the variance in the symptoms experienced.

Thus, given the negating influence of self-medication, mask usage, and personal sensitivity on the COVID-19 symptoms evidenced in this study, it becomes vital to curb self-medication, inadequate mask practice, and personal sensitivity beyond the current pandemic. The evidence on adverse outcomes from self-medication is quite broad to ignore the consequences. Research has likened self-medication to individual playing doctors and, in turn, is linked to substance abuse and poor medical literacy, which significantly endangered physical and mental health $(29,30)$. Before the pandemic in Europe, self-medication practice was associated with longstanding illness among the elderly and the severity of diseases $(31,32)$. With the emergence of the pandemic, the self-medication practice also underlines the problem in the healthcare systems for the safe management of diseases and substance/drug abuses. Self-medication can increase unreported COVID-19 cases, aggravate infections due to no testing and reporting of symptoms to medical doctors, and reduce the effect of medical intervention.

In psychomedical realities, sensitivity requires extensive research and attention for the groups liable to be victims during outbreaks of infectious diseases. The mental health vulnerabilities evidenced in the COVID-19 pan- demic is enormous (33). While the evidence in this study as pointed to personal sensitivity to getting infected with COVID-19 increases and predicts the symptoms, a proactive measure should therefore be adopted to reduce mental health vulnerabilities transcending to reduce belief of associated risks of getting infected.

\section{Research strength and limitations}

While mask usage, personal sensitivity, and self-medication have been explored in the context of the COVID-19 pandemic independently, no empirical evidence has adopted these three domains together conceptualized around COVID-19. Thus, the empirical evidence presented in this study presents a template for future research and potential intervention for the post-COVID-19 pandemic and guidance for intervention in any future pandemic. Policy and intervention for monitoring access to the over-the-counter pharmaceutical drug become necessary moving forward post-COVID-19 pandemic implementation. Strict global control of prescription medication and drugs will yield the desired result if policies are implemented at the community level to curtail self-medication. Mental health policies should be put in place post-COVID-19 pandemic to reduce the mental health effect of declaring a disease outbreak that may reduce the personal sensitivity to contracting the disease.

Numerous limitations hamper the generalization of our research findings, in particular, the small sample size of SSAs explored in making inferences about the episode of COVID-19 symptoms, self-medication, mask usages, and personal sensitivity. Given the coverage of the SSA participants, several countries are omitted from this research; the result should be interpreted accordingly. Based on findings and given the association and predictability of the variables investigated, it suffices that extensive study should be carried out by adopting a larger sample size.

\section{CONCLUSION}

Evidence of self-medication, poor mask usage, and personal sensitivity was reported in the survey as associated with increased symptoms in the study population. It further suggests the minimal hospital visit during the pandemic and risky health practices. These results call for continuous effort in ensuring good health practices among the global population until there is evidence of extermination of COVID-19. Steps towards the reduction of self-medication should be targeted to reduce the associated risks. More importantly, combating a global pandemic is a joint effort that requires all and sundry to engage in safe and healthy practices. Therefore, measures should be implemented to support Strict global control of prescription medication and drugs to reduce the mental health effect of declaring disease outbreaks. 
Informed Consent: Written consent was obtained from the participants.

Ethics Committee Approval: This study was approved by the Ethical Committee of the Nile University of Nigeria, Abuja (Date: 15.07.2020, No: NUN/DR/ERB/20/025).

Peer Review: Externally peer-reviewed.

Author Contributions: Conception/Design of Study- A.T.Y., S.C.; Data Acquisition- A.T.Y., O.I.O., T.A.E., T.C., A.F.O.; Data Analysis/Interpretation- A.T.Y., M.A.E., T.A.E., T.C., A.F.O.; Drafting Manuscript- A.T.Y., S.C., O.I.O., M.A.E., T.A.E., T.C., A.F.O.; Critical Revision of Manuscript- A.T.Y., S.C., O.I.O., M.A.E., T.A.E., T.C., A.F.O.; Approval and Accountability- A.T.Y., S.C., O.I.O., M.A.E., T.A.E., T.C., A.F.O

Conflict of Interest: Authors declared no conflict of interest

Financial Disclosure: Authors declared no financial support.

\section{REFERENCES}

1. Johns Hopkins University, Medicine, Coronavirus Resource Center, COVID-19 Map. (cited 2020 Sep 5). Available from: URL:https://coronavirus.jhu.edu/map.html.

2. Lee H, Moon SJ, Ndombi GO, Kim K, Berhe H, Nam EW. COVID-19 Perception, knowledge, and preventive practice: Comparison between South Korea, Ethiopia, and Democratic Republic of Congo. Afr J Reprod Health 2020;24(s1):66-77.

3. Serwaa D, Lamptey E, Appiah AB, Senkyire EK, Ameyaw JK. Knowledge, risk perception and preparedness towards coronavirus disease-2019 ( COVID-19) outbreak among Ghanaians : a quick online cross-sectional survey. Pan Afr Med J 2020;35(s2):1-7. [CrossRef]

4. Akintunde TY, Chen S, Di Q. Public health implication of displacement of Almajiri children in specific states of Northern Nigeria amidst COVID-19 pandemic. Ethics Med Public Health 2020;14:100544. [CrossRef]

5. Oyeniran Ol, Chia T. Novel coronavirus disease 2019 (COVID-19) outbreak in Nigeria: How effective are government interventions? Ethics Med Public Health 2020;14:100515. [CrossRef]

6. Al-Worafi YM. Self-medication. In Drug Safety in Developing Countries. Academic Press; 2020.p.73-86. [CrossRef]

7. Bennadi D. Self-medication: A current challenge. J Basic Clin Pharm 2014;5(1):19-23. [CrossRef]

8. Alghadeer S, Aljuaydi K, Babelghaith S, Alhammad A, Alarifi MN. Self-medication with antibiotics in Saudi Arabia. Saudi Pharm J 2018;26(5):719-24. [CrossRef]

9. Stevenson R, MacWalter RS, Harmse JD, Wilson E. Mortality during the Winter Flu Epidemic_-Two cases of death associated with self-medication. Scott Med J 2001;46(3):846. [CrossRef]

10. Scott N, Saul A, Spelman T, Stoove M, Pedrana A, Saeri $A$, et al. The introduction of a mandatory mask policy was associated with significantly reduced COVID-19 cases in a major metropolitan city. PLoS One 2021;16(7):e0253510. [CrossRef]
11. Cheng KK, Lam TH, Leung CC. Wearing face masks in the community during the COVID-19 pandemic: altruism and solidarity. Lancet 2020. [CrossRef]

12. Eikenberry SE, Mancuso M, Iboi E, Phan T, Eikenberry $K$, Kuang $Y$, et al. To mask or not to mask: Modeling the potential for face mask use by the general public to curtail the COVID-19 pandemic. Infect Dis Model 2020;5:293-308. [CrossRef]

13. Liu X, Zhang S. COVID-19: Face masks and human-to-human transmission. Influenza Other Respir Viruses 2020;14(4):472. [CrossRef]

14. Wang D, Sun BC, Wang JX, Zhou YY, Chen ZW, Fang Y, et al. Can masks be reused after hot water decontamination during the COVID-19 pandemic? Engineering 2020;6(10):1115-21. [CrossRef]

15. Costa L, Kropp JP. Linking components of vulnerability in theoretic frameworks and case studies. Sustain Sci 2013;8(1):1-9. [CrossRef]

16. González-Castro JL, Ubillos-Landa S, Puente-Martínez A, Gracia-Leiva M. Perceived vulnerability and severity predict adherence to COVID-19 protection measures: the mediating role of instrumental coping. Front Psychol 2021;12:674032. [CrossRef]

17. Timmermans DR, Henneman L, Hirasing RA, van der Wal G. Parents' perceived vulnerability and perceived control in preventing Meningococcal C infection: a large-scale interview study about vaccination. BMC Public Health 2008;8(1):1-7. [CrossRef]

18. Welling LL, Conway CA, Debruine LM, Jones BC. Perceived vulnerability to disease is positively related to the strength of preferences for apparent health in faces. J Evol Psychol 2007;5(1):131-9. [CrossRef]

19. Coronavirus disease (COVID-19), 2020. (cited 2020 Sept 10). Available from: URL: https://www.who.int/news-room/q-adetail/coronavirus-disease-covid-19. [CrossRef]

20. Bryan AD, Aiken LS, West SG. Young women's condom use: The influence of acceptance of sexuality, control over the sexual encounter, and perceived susceptibility to common STDs. Health Psychol 1997;16(5):468. [CrossRef]

21. Kim J, Park HA. Development of a health information technology acceptance model using consumers' health behavior intention. J Med Internet Res 2012;14(5):e133. [CrossRef]

22. Cohen P, West SG, Aiken LS. Applied multiple regression/ correlation analysis for the behavioral sciences. Psychology Press; 2014. [CrossRef]

23. Viner RM, Mytton OT, Bonell C, Melendez-Torres GJ, Ward J, Hudson L, et al. Susceptibility to SARS-CoV-2 infection among children and adolescents compared with adults: a systematic review and meta-analysis. JAMA Pediatr 2021;175(2):143-56. [CrossRef]

24. Wang $Y$, Tian $H$, Zhang $L$, Zhang $M$, Guo D, Wu W, et al. Reduction of secondary transmission of SARS-CoV-2 in households by face mask use, disinfection and social distancing: a cohort study in Beijing, China. BMJ Glob Health 2020;5(5):e002794. [CrossRef]

25. Onchonga D, Omwoyo J, Nyamamba D. Assessing the prevalence of self-medication among healthcare workers before and during the 2019 SARS-CoV-2 (COVID-19) pandemic in Kenya. Saudi Pharm J 2020;28(10):1149-54. [CrossRef] 
26. Yıldırım M, Güler A. Factor analysis of the COVID-19 perceived risk scale: A preliminary study. Death Stud 2020:1-8. [CrossRef]

27. Cohen S, Alper CM, Doyle WJ, Adler N, Treanor JJ, Turner RB. Objective and subjective socioeconomic status and susceptibility to the common cold. Health Psychol 2008;27(2):268. [CrossRef]

28. De Coninck D, d'Haenens L, Matthijs K. Perceived vulnerability to disease and attitudes towards public health measures: COVID-19 in Flanders, Belgium. Pers Individ Dif 2020;166:110220. [CrossRef]

29. Levy M. The many faces (and potential dangers) of selfmedication as an explanatory concept for substance use. Int J Adv Couns 2019;41(1):15-24. [CrossRef]

30. Lee $\mathrm{CH}$, Chang FC, Hsu SD, Chi HY, Huang LJ, Yeh MK. Inappropriate self-medication among adolescents and its association with lower medication literacy and substance use. PLoS One 2017;12(12):e0189199. [CrossRef]
31. Brandão GR, Teixeira L, Araújo L, Paúl C, Ribeiro O. Selfmedication in older european adults: Prevalence and predictive factors. Arch Gerontol Geriatr 2020;91:104189. [CrossRef]

32. Lei $X$, Jiang H, Liu C, Ferrier A, Mugavin J. Self-medication practice and associated factors among residents in Wuhan, China. Int J Environ Res Public Health 2018;15(1):68. [CrossRef]

33. Akintunde TY, Musa TH, Musa HH, Musa IH, Chen S, Ibrahim $\mathrm{E}$, et al. Bibliometric analysis of global scientific literature on effects of COVID-19 pandemic on mental health. Asian J Psychiatr 2021;63:102753. [CrossRef] 